\title{
The Impact of the Pharmaceutical Pricing System on Cost-Effectiveness Results: Finnish Analysis
}

\author{
Taru Hallinen ${ }^{*}$ and Erkki J. Soini
}

ESiOR Oy, Tulliportinkatu 2 LT 4, 70100 Kuopio, Finland

\begin{abstract}
In Finland, the drug retail prices are determined with a regressive pharmaceutical pricing scheme (PPS) that leads to higher absolute sales margins for products with higher wholesale prices. At the same time low-priced products are sold at prices below the true costs of drug delivery. Despite these characteristics retail prices are used to represent all drug costs in health economic evaluations that are required before societal reimbursement of new drugs can be granted. We assessed the impact of PPS induced cost differences on the results of cost-utility analyses in hypothetical examples. The examples show that the Finnish PPS worsens the ICERs obtained for more expensive pharmaceuticals. The Finnish PPS is problematic when the aim is to provide Finnish patients with optimal, cost-effective treatments. In its current form, the PPS discourages innovation and comparability of results with other settings, and may prevent reimbursement of otherwise cost-effective treatments.
\end{abstract}

Keywords: Cost-utility, Finland, Incentives, Pharmaceuticals, Price regulation, Reimbursement.

\section{BACKGROUND}

Two- or three-tier financing of pharmaceuticals is a reality in Finland (see [1-4]). The Finnish Social Insurance Institution (SII) reimburses the drugs that have been granted reimbursement status, have official retail prices and are dispensed through retail pharmacies or private hospitals. Municipalities pay for the drugs that are administered in publicly funded hospitals, and drugs that are not administered in public hospitals or are not reimbursed are paid for by the patient.

The health economic (HE) and clinical values, as well as reasonable wholesale prices, of new pharmaceuticals have to be demonstrated before a positive decision from the Finnish Pharmaceuticals Pricing Board (PPB) can be obtained and before the drug is eligible for reimbursement by the Finnish SII [5]. HE reassessments are also required by the PPB for reimbursed products to maintain their eligibility. According to the Finnish guidelines [6], the HE value and reasonable wholesale price should be demonstrated with a full health economic evaluation (typically, cost-effectiveness analysis, CEA) of the drug compared to the most commonly used and, typically, the most affordable treatment alternative. HE assessments are seen as a means of maximizing the societal benefits with the available limited resources.

The CEA-type HE evaluations focus on the simultaneous assessment of outcomes related to the new treatment (clinical or quality of life, QoL) and costs in the indicated disease compared to the currently used treatment alternatives. Most published guidelines (see e.g. [6, 7]) require that all relevant direct health care costs associated with the compared treatments are included for the CEAs to be valid. Cost differences between treatment alternatives typically result

*Address correspondence to this author at the ESiOR Oy, Tulliportinkatu 2 LT 4, 70100 Kuopio, Finland; Tel: 358505681894 ;

E-mail: taru.hallinen@esior.fi from increased survival/safety, different drug prices and reductions or increases in the use of other health care resources. In many CEAs, other direct costs (e.g. travelling costs) and productivity losses are also accounted for. In Finland, the recommended perspective in the CEA is the direct health care cost perspective, including drug and other direct treatment costs related to the disease in question regardless of who actually pays those costs (travelling costs may be included if considered relevant) [6].

The results of CEAs are typically reported as incremental cost-effectiveness ratios (ICER), which are estimated as the quotient of the cost and outcome differences in the studied treatments. There is no exact threshold or willingness-to-pay (WTP) level for the ICER that would be considered to confirm the CE (value for money) of treatments in Finland. Often, a threshold of $€ 50,000$ or twice the GNP per inhabitant (ca. €70,000 in Finland) per quality adjusted lifeyear (QALY) gained are used as reference values for the ICER. In line with these reference values, the maximum WTP of Finnish health district politicians and physicians in a survey setting centred on $€ 50,000$ - $€ 120,000$ per QALY gained, depending on the disease/treatment [8].

In 2010 , the drug reimbursement costs decreased by $€ 16$ million (1.6\%) in Finland [9] compared to the previous year - this is probably due to the reference pricing system and wide generic competition that were postulated by the analogy process patents common in Finland that enabled generic competition for drugs that were still protected by product patents in other countries (e.g. [10]). In the Finnish system, retail drug prices are determined using a computational PPS that is based on the wholesale price. The PPS has been designed to be regressive, but it nevertheless provides higher absolute pharmacy margins for drugs with high wholesale prices. As a result of the PPS, drugs with low wholesale prices have sales margins that do not cover the costs of dispensing those drugs from pharmacies, whereas drugs with high wholesale prices have sales margins 
significantly exceeding the costs of dispensing. Despite these features of the PPS, the retail prices without value added tax (VAT; 9\% in year 2011) are used in HE evaluations as the total drug cost [6], which is therefore assumed to consist of the cost of distribution in addition to the pharmaceutical wholesale price. In this study we assess the impact of the Finnish PPS on the results of CEAs using hypothetical examples with real life anchors.

\section{METHODS}

The impact of PPS was assessed in multiple hypothetical CEA scenarios in which two drug treatments, generic (A) and patented/branded (B), were compared by assuming that drug B improves the QoL of patients but does not differ from drug A with regard to the use of other health care resources, survival or actual drug distribution costs.

The structure of the Finnish PPS is shown in Table $\mathbf{1 .}$ The wholesale price in Table $\mathbf{1}$ is the price at which Finnish pharmacies can buy pharmaceutical products from the pharmaceutical wholesalers i.e. in addition to the cost of drug (ex-factory price) it includes drug distribution costs of the wholesalers (the distribution margins in Finland are privately negotiated between drug industry and pharmaceutical wholesalers). Let us assume that wholesale prices for the drugs $A$ and $B$ are $€ 4.00$ and $€ 200.00$, respectively, for 100 tablets (once daily treatment). Based on the PPS, the retail prices (excluding VAT) are, therefore, $€ 6.50$ for drug $A$ and $€ 256.15$ for drug B. The cost difference between drugs $A$ and $B$ is, therefore, $€ 249.65$ with retail prices and $€ 196.00$ with wholesale prices. The difference between these two, i.e. $€ 53.65$ in this example, is from now on referred to as the PPS-induced cost difference. In the Finnish setting, the PPS-induced cost difference is purely computational and is not based on any real current drug distribution/dispensing cost.

Since this is a study demonstrating the potential impact of the PPS on CEA results, we assume that only drug costs increase and QoL improves when drug B is compared to drug $\mathrm{A}$ in the CEA. For simplicity, we assume that the survival and health care resource use are unaffected. In a Finnish nation-wide study [11], loss of hearing, depression, diabetes, coronary heart disease (CHD), rheumatoid arthritis (RA) and Parkinson's disease were associated with an independent, EQ-5D measured annual QoL loss of 0.004, $0.091,0.041,0.011,0.083$ and 0.143 , respectively. We further assume that drug B is able to fully remove the QoL losses in these conditions for a one-year period (i.e. the QALYs gained with drug B compared to drug A are equivalent with the EQ-5D measured QALY losses during the one-year period).

Table 1. Finnish Drug Pricing Scheme (Valtioneuvoston Asetus Lääketaksasta 11.12.2002/1087)

\begin{tabular}{|c|c|}
\hline Wholesale Price & Retail Price \\
\hline \hline$€ 0-9.25$ & $1.5 \times$ wholesale price $+€ 0.50$ \\
\hline$€ 9.26-46.25$ & $1.4 \times$ wholesale price $+€ 1.43$ \\
\hline$€ 46.26-100.91$ & $1.3 \times$ wholesale price $+€ 6.05$ \\
\hline$€ 100.92-420.47$ & $1.2 \times$ wholesale price $+€ 16.15$ \\
\hline$>€ 420.47$ & $1.125 \times$ wholesale price $+€ 47.68$ \\
\hline
\end{tabular}

The incremental cost-effectiveness ratios (ICER) per QALY gained and the PPS-induced change in the ICERs were estimated in the following six scenarios using different wholesale prices for drugs A and B, respectively: 1) $€ 4$ and $€ 200$ per 100 tablets; 2) $€ 5$ and $€ 20$ per 100 tablets; 3) $€ 5$ and $€ 100$ per 100 tablets; 4) $€ 10$ and $€ 500$ per 100 tablets; 5) $€ 50$ and $€ 1000$ per 100 tablets; and 6) $€ 100$ per 100 tablets and $€ 1$ 000 per month. Some of these example analyses have real life anchors. In the Finnish context, scenario 1 roughly corresponds to a comparison between citalopram $20 \mathrm{mg}$ ( $€ 4.21$ for $20 \mathrm{mg} 100$ tabl with the cheapest alternative, 9\% VAT included) and agomelatine $25 \mathrm{mg}$ ( $€ 198.05$ for $25 \mathrm{mg} 98$ tabl, $9 \%$ VAT included), scenario 3 could be a comparison between simvastatin $20 \mathrm{mg}$ (reference price $€ 6.20$ for $20 \mathrm{mg} 98$ tabl, $9 \%$ VAT included) and branded rosuvastatin $10 \mathrm{mg}$ ( $€ 110.99$ for 10mg 98 tabl, 9\% VAT included), scenario 4 roughly corresponds the comparison between metformin $1 \mathrm{~g}$ (reference price $€ 10.55$ for $1 \mathrm{~g} 100$ tabl, 9\% VAT included) and exenatide 5 mikrogram twice daily ( $€ 120.49$ for 5 mikrogram $60 \mathrm{dos}, 9 \%$ VAT included), and scenario 6 could be a comparison between methotrexate 10mg daily (€96.04 for $10 \mathrm{mg} 100$ tabl, 9\% VAT included) and etanercept $4 \times 50 \mathrm{mg}$ per month ( $€ 1243.81$ for 4x50mg inj, 9\% VAT included).

\section{RESULTS}

The ICERs in the estimated scenarios range from $€ 547$ to $€ 3.4$ million per QALY gained when estimated with retail

Table 2. Incremental Cost-Effectiveness Ratios (ICER) Based on Retail Prices (Assumed Difference in QALYs Gained at the Annual Level in Parentheses)

\begin{tabular}{|c|c|c|c|c|c|c|c|}
\hline \multicolumn{2}{|c|}{$\begin{array}{l}\text { Cost Difference }(\epsilon) \text { in } \\
\text { Scenarios 1-6 }\end{array}$} & \multirow{2}{*}{$\begin{array}{c}\begin{array}{c}\text { Loss of Hearing } \\
(\mathbf{0 . 0 0 4 )}\end{array} \\
227806\end{array}$} & \multirow{2}{*}{$\begin{array}{c}\begin{array}{c}\text { CHD } \\
(\mathbf{0 . 0 1 1 )}\end{array} \\
82838\end{array}$} & \multirow{2}{*}{$\begin{array}{c}\begin{array}{c}\text { Diabetes } \\
\mathbf{( 0 . 0 4 1 )}\end{array} \\
22225\end{array}$} & \multirow{2}{*}{$\begin{array}{c}\begin{array}{c}\text { RA } \\
(\mathbf{0 . 0 8 3})\end{array} \\
10979\end{array}$} & \multirow{2}{*}{$\begin{array}{c}\begin{array}{c}\text { Depression } \\
\mathbf{( 0 . 0 9 1 )}\end{array} \\
10013\end{array}$} & \multirow{2}{*}{$\begin{array}{c}\begin{array}{c}\text { Parkinson's Disease } \\
(\mathbf{0 . 1 4 3 )}\end{array} \\
6372\end{array}$} \\
\hline 1 & 911 & & & & & & \\
\hline 2 & 78 & 19555 & 7111 & 1908 & 942 & 860 & 547 \\
\hline 3 & 467 & 116846 & 42489 & 11400 & 5631 & 5136 & 3268 \\
\hline 4 & 2171 & 542709 & 197349 & 52947 & 26155 & 23855 & 15181 \\
\hline 6 & 13576 & 3393894 & 1234143 & 331112 & 163561 & 149182 & 94934 \\
\hline
\end{tabular}

Wholesale prices of drugs A and B in scenarios 1-6: 1) $€ 4$ and $€ 200$ per 100 tablets; 2) $€ 5$ and $€ 20$ per 100 tablets; 3) $€ 5$ and $€ 100$ per 100 tablets; 4$) € 10$ and $€ 500$ per 100 tablets; 5 ) $€ 50$ and $€ 1000$ per 100 tablets; and 6) $€ 100$ per 100 tablets and $€ 1000$ per month. 
prices (Table 2). Of the retail price-based cost differences between drugs A and B, $14 \%-30 \%$ are due to the Finnish PPS, respectively.

The PPS-induced cost differences vary from $€ 23$ (scenario 2) to $€ 1941$ (scenario 6) at the annual level. As shown in Table $\mathbf{3}$, these cost differences increase the estimated ICERs by $€ 164$ to $€ 485144$ per QALY gained. For example, if TNF inhibitors (such as etanercept) were not approved until now and their $\mathrm{CE}$ was assessed in comparison with methotrexate, the mere extra computational drug distribution costs allocated to the new treatment by the Finnish system could increase the ICER by some $€ 23380$ if the number of annual QALYs gained were 0.083. The impact is large enough to potentially impact on whether treatments are considered cost-effective and eligible for reimbursement. For example, in scenario 4, the ICER for diabetes would be $€ 52947$ per QALY gained based on retail prices (Table 2), whereas the ICER would be $€ 43622$ per QALY gained ( $€ 9325$ lower from Table 3) if PPS-induced cost difference is excluded.

Fig. (1) depicts the impact of the cost difference on the ICER per QALY gained when the QALYs gained at the annual level are varied. As can be seen from the figure, the impact of the computational, PPS-induced cost difference on the ICERs increases when fewer QALYs are gained at the annual level. With the exception of scenario 6, the impact becomes relatively small when the QALYs gained approach 0.2 per year. However, the annual disutility associated with different disorders is rarely that high. Among the 29 conditions studied in Saarni et al., [11], the annual QALY losses varied from 0.004 (loss of hearing) to 0.143 (Parkinson's disease).

\section{DISCUSSION}

The Finnish PPS creates computational cost differences between drugs that are not based on the actual cost differences in drug delivery/dispensing. In the scenarios presented in this exercise, the ICERs per QALY increased by $€ 164$ to $€ 485144$ because of the PPS-induced cost differences. The magnitude of the changes in ICERs can be considered rather large in comparison with the often used thresholds of $€ 50,000$ - $€ 70,000$ per QALY gained. In addition, in comparison with the ICERs obtained in previous Finnish analyses among the example diseases [10, 12-15], these PPS-induced ICER increases are significant. In many cases, the PPS-induced computational cost differences could even impact on whether the new treatment is considered cost-effective and eligible for societal reimbursement.

Due to the two-tier financing system, similar challenges occur when reimbursed drug treatments are being compared with hospital-administered drug treatments (see $[12,16])$ or treatments that have market authorization but are not reimbursed. For hospital-administered drug treatments, the wholesale price can be a suitable drug cost estimate. However, for reimbursed drugs, we need to use the retail price without VAT. Thus, in the comparison between pharmacy and hospital products, the computational PPS distorts the CEA results even more than can be seen based on our examples.

Naturally, the impact of PPS-induced cost differences on the results of the CEAs is highly dependent on the benefit obtained from the new treatment: the smaller the extra benefit, the larger the impact of PPS-induced cost differences. For many treatments (e.g. preventive treatments), the annual benefit measured as QALYs gained can be relatively small. In our scenarios we assumed that the annual QALY loss associated with certain conditions (ranging from $0.004-0.143$ ) in Finland could be removed with a new treatment, and the cost difference is due to drug costs. For simplicity, we assumed that the patients' QoL would improve as a result of the new drug without any simultaneous changes in mortality or use of other health care resources. These changes occur in most evaluations and may reduce or increase the cost difference between the new and old treatments. Inclusion of these impacts would not, however, have changed the impact of the PPS-induced cost differences on the ICERs given the setting here. Overall, our analysis highlights that the drug pricing system can have a notable impact on the $\mathrm{CE}$ results. To improve the generalization of results between countries, it might be beneficial to report the study results based on the wholesale prices of drugs $[12,16]$ or equal drug distribution costs when no true rationale for using different drug distribution costs exists.

The Finnish practice of using PPS-based retail prices to represent the sum of drug and drug distribution costs for low-priced drugs violates the official requirement (see $[5,6])$ to include all costs of treatment comparators in $\mathrm{HE}$

Table 3. The Impact of Finnish Drug Pricing Scheme-Induced Computational Cost Differences on ICERs of Cost Per QALY Gained (in Euros) in Certain Conditions (Assumed Difference in QALYs Gained at the Annual Level in Parentheses)

\begin{tabular}{|c|c|c|c|c|c|c|c|}
\hline \multicolumn{2}{|c|}{$\begin{array}{c}\text { Cost Difference (€) } \\
\text { in Scenarios 1-6 }\end{array}$} & $\begin{array}{c}\text { Loss of Hearing } \\
(\mathbf{0 . 0 0 4 )}\end{array}$ & $\begin{array}{c}\text { CHD } \\
(\mathbf{0 . 0 1 1})\end{array}$ & $\begin{array}{c}\text { Diabetes } \\
(\mathbf{0 . 0 4 1})\end{array}$ & $\begin{array}{c}\text { RA } \\
(\mathbf{0 . 0 8 3})\end{array}$ & $\begin{array}{c}\text { Depression } \\
(\mathbf{0 . 0 9 1})\end{array}$ & $\begin{array}{c}\text { Parkinson's Disease } \\
(\mathbf{0 . 1 4 3})\end{array}$ \\
\hline \hline $\mathbf{1}$ & 196 & 48956 & 17802 & 4776 & 2359 & $2152^{*}$ & 1369 \\
\hline $\mathbf{2}$ & 23 & 5867 & 2134 & 572 & 283 & 258 & 164 \\
\hline $\mathbf{3}$ & 121 & 30158 & $10967+$ & 2942 & 1453 & 1326 & 844 \\
\hline $\mathbf{4}$ & 382 & 95584 & 34758 & 9325 & 4606 & 4202 & 2674 \\
\hline $\mathbf{5}$ & 553 & 138362 & 50314 & 13499 & 6668 & 6082 & 3870 \\
\hline $\mathbf{6}$ & 1941 & 485144 & 176416 & 47331 & $23380^{\$}$ & 21325 & 13570 \\
\hline
\end{tabular}

Wholesale prices of drugs A and B in scenarios 1-6: 1) $€ 4$ and $€ 200$ per 100 tablets; 2) $€ 5$ and $€ 20$ per 100 tablets; 3) $€ 5$ and $€ 100$ per 100 tablets; 4$) € 10$ and $€ 500$ per 100 tablets; 5 ) $€ 50$ and $€ 1000$ per 100 tablets; and 6$) € 100$ per 100 tablets and $€ 1000$ per month. * agomelatine $25 \mathrm{mg} v s$ citalopram $20 \mathrm{mg}, \dagger$ rosuvastatin $10 \mathrm{mg} v s$ simvastatin $20 \mathrm{mg}, \ddagger$ exenatide $5 \mathrm{mg}$ twice daily $v s$ metformin $2 \mathrm{~g}$, and $\$$ etanercept $4 \mathrm{x} 50 \mathrm{mg}$ per month $v s$ methotrexate $10 \mathrm{mg}$. 


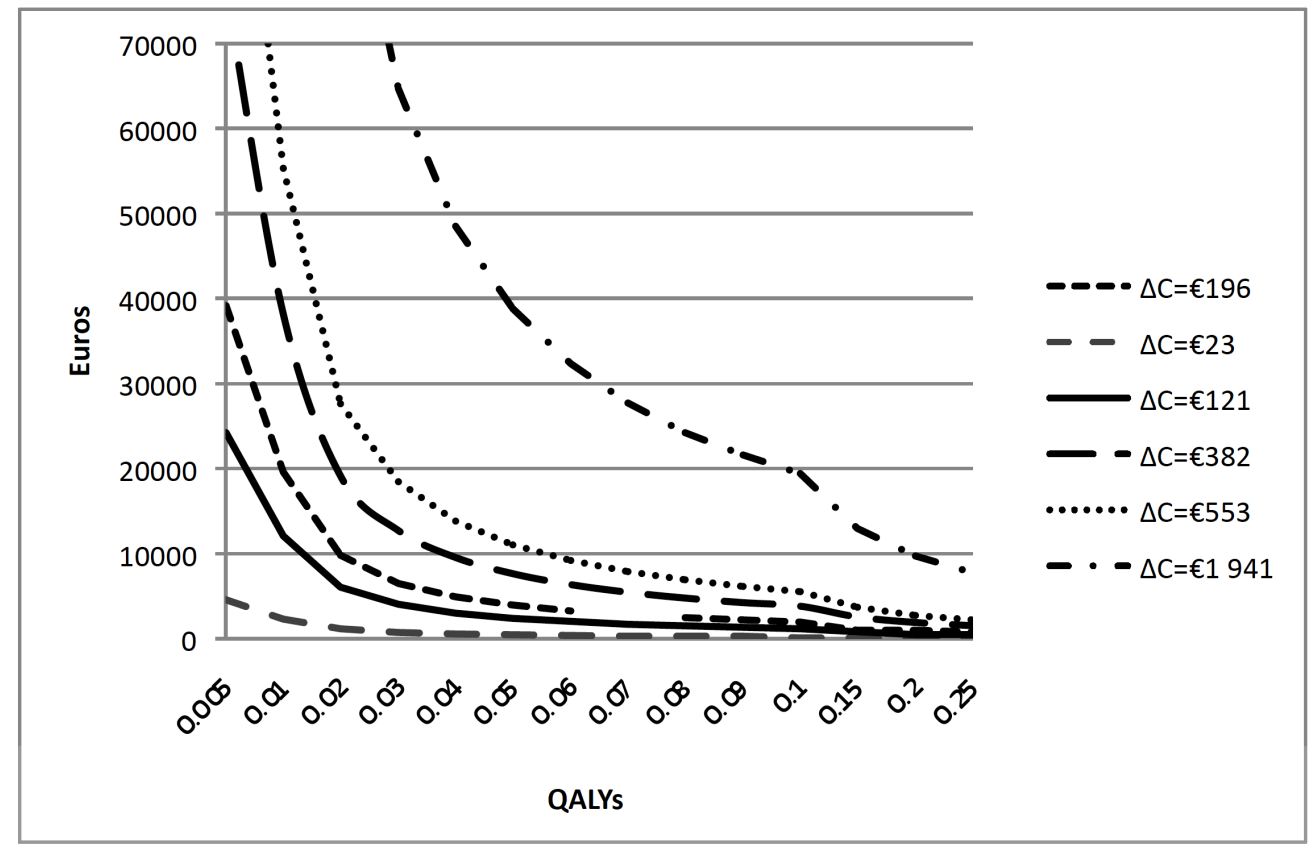

Fig. (1). The impact of PPS-induced cost difference in different scenarios. $\Delta \mathrm{C}=$ cost difference induced by the Finnish PPS.

evaluations; the mere labour costs of drug dispensing at Finnish pharmacies has been estimated at $€ 5.81$ per prescription in 2007 [17] and the retail prices for the cheapest drugs are too low to cover these costs. Based on the current PPS, the wholesale price of any drug should be at least $€ 10.95$ for the retail price-based $(€ 16.76)$ sales margin to cover the labour costs associated with dispensing the drug. Even in this case, not all costs in drug distribution will be covered (rent, storage, etc.). On the contrary, the retail prices of drugs with higher wholesale prices may exceed the total costs of the wholesale price and drug distribution. Thus the Finnish PPS, perhaps unintentionally, entails the idea that more expensive drugs should partially fund the use of cheaper drugs. Because the Finnish reimbursement system covers the cost of most drugs only partially (the basic reimbursement covers $42 \%$ and special reimbursement covers $72 \%$ or $100 \%$ of the drug cost), the patients needing more expensive drugs actually end up subsidising the drugs for patients who can be treated with cheaper drugs. Although the annual maximum patient deductible (675.39 Euros in 2011) limits the size of cross-subsidies, this kind of system treats patients unequally. At the European level, the Finnish pricing system has led to lower wholesale prices but higher retail prices compared with many other countries (see e.g. [18]).

In our opinion, the Finnish PPS does not represent the drug costs properly and is outdated when considering the current requirements for granting a reimbursement status for drugs. When the Finnish PPS was originally developed, there was no strict requirement to demonstrate the $\mathrm{HE}$ value (CEA) and reasonability of the wholesale price of pharmaceutical products in Finland. Furthermore, generic substitution of drugs was not allowed, analogy method patents were valid and the current reference pricing system was not in use. All these changes have taken place while the structure of the PPS has remained unchanged. Recently, the Finnish officials have proposed some changes for the pricing scheme [19]. The suggested changes maintain the original pricing scheme structure which applies a regressive multiplier for the wholesale price plus a progressive lump sum for each increasing wholesale price category. Essentially the suggested new scheme still forces the prices of cheapest drugs below their true societal cost. The suggested changes would, however, reduce the pricing scheme induced cost difference between expensive and cheap drugs.

The PPS should be developed to treat drugs equally, regardless of whether they have high (i.e. usually patented and new drugs) or low (i.e. usually old and generic drugs) wholesale prices. At least the full drug distribution costs should be incorporated in the retail prices of drugs with low wholesale prices. When CEAs are performed from societal perspective the drug costs should be estimated independently of the income transfers (i.e. cross-subsidy between the expensive and cheap drugs) that are inherent in the current PPS. The current Finnish practice of assessing the HE value of new drugs based on CEAs that use retail prices without VAT as drug costs can put new, innovative and more expensive drugs at a considerable disadvantage. Meanwhile, the current care is hard to define and off-label treatments are used (see [20]). As a result, the Finnish drug pricing scheme can form a disincentive to innovation.

It would be interesting to find out whether price regulation practices in other countries have similar (or different) characteristics that can distort CEAs or form crosssubsidies that are hard to detect due to their implicit nature. To our knowledge no such studies have yet been published. The scope of our analysis was restricted to Finland simply because it is the system that we are most familiar with. We also acknowledge that in real life there are more CEA scenarios than were covered in our short analysis. However, increasing the number of scenarios wouldn't have changed the findings of our study. 


\section{CONCLUSIONS}

The Finnish PPS increases the ICERs obtained in HE evaluations when drugs with high and low wholesale prices are compared by inducing computational cost differences and cross-subsidies between them. As such, the Finnish system puts new, innovative and more expensive drugs at an unnecessary disadvantage compared to older, generic products. The magnitude of the impact is large enough to potentially distort or even bias CEAs and may impact on the drug's eligibility for societal reimbursement.

\section{REFERENCES}

[1] Teperi J, Porter ME, Vuorenkoski L, Baron JF. The Finnish health care system: a value-based perspective. Helsinki: Sitra reports 82, 2009.

[2] Häkkinen U. The impact of changes in Finland's health care system. Health Econ 2005; 14(Suppl 1): S101-18.

[3] OECD Reviews of Health Systems: Finland. OECD, 2005.

[4] Hermanson T, Aro S, Bennett CL. Finland's health care system. Universal access to health care in a capitalistic democracy. J Am Med Assoc 1994; 271: 1957-62.

[5] Kivioja A. Lääketaloudellisen arvioinnin rooli lääkkeiden tukkuhinta- ja korvattavuuspäätöksissä (The role of pharmacoeconomic evaluations in the whole sale price and reimbursement decisions). Dosis 2006; 22: 301-7.

[6] Ohje terveystaloudellisen selvityksen laatimiseksi (Guidelines for preparing a health economic evaluation). Appendix to the decree 201/2009 by the Ministry of Social Affairs and Health, Finland.

[7] Pharmacoeconomic Guidelines around the World. Lawrenceville: ISPOR, 2011. Available [accessed $3^{\text {rd }}$ April 2011]: http://www.ispo r.org/PEguidelines/index.asp

[8] Soini EJ, Kukkonen J, Myllykangas M, Ryynänen OP. What is politician's and clinician's willingness to pay (WTP) for future health benefit based on 15D, EQ-5D and life-years? A contingent valuation (CV) among 8 diseases with the total of 1092 cases. In: Abstracts of the ISPOR (International Society for Pharmacoeconomics and Outcomes Research) Eleventh Annual European Congress. November 8-11 2008, Athens, Greece. Value Health 2008; 11: A556.

[9] Lääkekorvaukset pienenivät 19 miljoonaa euroa (Drug reimbursements decreased by 19 million Euros) [Announcement on the internet]. Kela tiedottaa 2011; 4.3 [cited $3^{\text {rd }}$ April 2011]. Available from: http://www.kela.fi/in/internet/suomi.nsf/NET/040 311101609PM?OpenDocument

[10] Salokannel M, Hjelt P, Höykinpuro R, Lapiolahti S, Lindberg J, Vuorinen $\mathrm{J}$. The impact of public health issues on exclusive patent rights [Report on the internet]. AIPPI report Q202 [cited $20^{\text {th }}$ October 2011]. Available from: https://www.aippi.org/download/ commitees/202/GR202finland.pdf
Saarni SI, Härkänen T, Sintonen H, et al. The impact of 29 chronic conditions on health-related quality of life: a general population survey in Finland using 15D and EQ-5D. Qual Life Res 2006; 15: 1403-14.

[12] Hallinen TA, Soini EJ, Eklund K, Puolakka K. Cost-utility of different treatment strategies after the failure of tumour necrosis factor inhibitor in rheumatoid arthritis in the Finnish setting. Rheumatology (Oxford) 2010; 49: 767-77.

[13] Soini EJ, Hallinen TA, Kauppi MJ, Vihervaara V, Puolakka K. Comprehensive health economic assessment of sequenced treatment with biologics in moderate-to-severe rheumatoid arthritis: Analysis based on ACR50 and ACR70 responses. In: Abstracts of the American College of Rheumatology/Association of Rheumatology Health Professionals Annual Scientific Meeting Atlanta, Georgia November 6-11, 2010. Arthritis Rheum 2010; 62(Suppl 10): 759.

[14] Soini EJ, Hallinen TA. Health economic study using survey data and modelling: Agomelatine, generic venlafaxine and placebo in the treatment of major depressive disorder. In the abstract book of $8^{\text {th }}$ European Conference on Health Economics, Helsinki, Finland, July 7-10, 2010 [cited $3^{\text {rd }}$ April 2011]. Available from: http://eche2 010.abstractbook.org/presentations/254/

[15] Soini EJ, Stevenson MD, Martikainen JA, Akehurst RL. Costutility of bosentan in the first-line treatment of pulmonary arterial hypertension in Finland - A discrete event simulation modelling. In: ISPOR (International Society for Pharmacoeconomics and Outcomes Research) $12^{\text {th }}$ Annual European Congress, October 2427, 2009, Paris, France. Value Health 2009; 12: A335.

[16] Soini EJ, García San Andrés B, Joensuu T. Trabectedin in the treatment of metastatic soft tissue sarcoma: cost-effectiveness, costutility and value of information. Ann Oncol 2011;22: 215-23.

[17] Harjula I. Ovatko yrittäjän työkalut apteekkarin käytössä? (Can the conventional business tools be employed by pharmacy owners?) In: Lääkepäivät, 2008, Kuopio.

[18] Martikainen J, Kivi I, Linnosmaa I. European prices of newly launched reimbursable pharmaceuticals - a pilot study. Health Policy 2005; 74: 235-46.

[19] Fimea. Valtioneuvoston asetus lääketaksasta ja sairausvakuutuslain mukainen lääkekulujen vuotuinen potilaskohtainen omavastuu (Finnish government's decree on pharmaceutical fees and the annual patient deductible for pharmaceuticals according to Sickness Insurance Act). Muistio 6.7.2011. [Cited 19 ${ }^{\text {th }}$ August 2011]. Available from: http://www.fimea.fi/instancedata/prime $p$ roduct_j ulkaisu/fimea/embeds/fimeawwwstructure/18688_Fimea n_ehdotus_laaketaksa_ja_vuotuinen_laakekulujen_omavastuu_6_7 2011.pdf

[20] Soini E. Harvinaissairauksien taloudellinen arviointi: mitä päätöksien tueksi tulisi tuottaa? (Health economic assessment of orphan diseases: what kind of information should be produced to support decision making?) Harvinaiset Sairaudet -lehti 2011; 1:2631 .

(C) Hallinen and Soini; Licensee Bentham Open.

This is an open access article licensed under the terms of the Creative Commons Attribution Non-Commercial License (http://creativecommons.org/licenses/by$\mathrm{nc} / 3.0 /$ ) which permits unrestricted, non-commercial use, distribution and reproduction in any medium, provided the work is properly cited. 